\title{
Creative Intervention
}

\section{The Northern Edge of Everything}

\author{
TERRY TROWBRIDGE ${ }^{1}$ \\ York University, Canada
}

JADE WALLACE ${ }^{2}$

Canada

For the first three of the four years that we lived in Toronto together, we rented a condo next to the last stop on the northwest end of Toronto's subway system. Then called Downsview, now called Sheppard West for reasons that have some unclear relation to a subway expansion that was locked in suspended animation for years, it is the station "at the lonely edge of everything, at the centre of nothing" ("The Northern Edge of Everything"). It is located on the dividing lines of three neighbourhoods - Downsview, Bathurst Manor, and York University Heights - and it stands beside an industrial-looking Downsview Park and within view of the clamour of Downsview Airport. The neighbourhood is a contested space, as real estate developers, international investors, and immigrant communities move like tides across the Greater Toronto Area. The geographical marginality of the space both mirrors and entrenches the marginalized identities of its inhabitants, many of whom are racialized persons, precariously employed persons, newcomers, recipients of social assistance, or seniors.

\footnotetext{
${ }^{1}$ Terry Trowbridge is a PhD student in Socio-Legal Studies at York University. His poems have appeared in Draft, CV2, The New Quarterly, The Dalhousie Review, The Nashwaak Review, Paperplates, Untethered, Carousel, Briarpatch, The Great Lakes Review, Orbis, The Broadkill Review, (parenthetical), The Prairie Journal, subTerrain, and elsewhere. He has five chapbooks from Grey Borders Books.

${ }^{2}$ Jade Wallace is a Toronto legal clinic worker whose poetry and prose have been published in Canada, the United States, the United Kingdom, Ireland, and New Zealand, and have appeared in publications including The Dalhousie Review, The Nashwaak Review, In/Words, Draft,

Feathertale, A New Ulster, Acumen, and The Antigonish Review. Jade's work has also been featured in the anthologies Pac'n Heat: A Noir Homage To Ms. Pac-Man from AGP Books and Breakfast In A Day from Death Cookie Soup Press, as well as seven chapbooks from Grey Borders Books.
} 
The neighbourhood is part of what is sometimes called North York, sometimes called Toronto. It is legally regarded as both, even recognized as such by Canada Post, but the choice of name typically reflects how long someone has lived there. Longstanding residents are likely to call it North York, in memory of the time when it was a city unto itself. Newer residents who want to pretend that gentrification hasn't pushed them to the periphery of the city they want to live in call it Toronto.

The streets are a combination of empty houses waiting several years to be demolished, ersatz villas and high-rise condo buildings replacing tiny affordable bungalows, intersections of heavy traffic that moves without attention to stop lights, lines on the road, or pedestrians, and an array of small businesses struggling to convince the locals to stay close rather than make the long trek downtown to locations more profitable for multi-million dollar corporations. It is a place "where a Porsche parks next to a/ K-car on blocks" ("Balcony Birding") and where "Poverty is not hidden-/ it is in the decrepit houses right next to the expensive condos" ("No Secrets"). Such juxtapositions trouble the straightforward celebration of mixed-economicclass neighbourhoods so lauded in recent years by the Toronto municipal government, and point to the uneasiness that characterizes neighbourhoods where "We know exactly what everyone's income is" ("No Secrets") and there is significant economic disparity among residents. Though resources and capital eventually follow the middle and upper class when they move in, there is also tension that results from dislocation and its resultant fractures of communities in which people once lived with others who shared many of their economic and social experiences. The fact remains that mixing economic classes in a building, or in a neighbourhood, even when it lowers crime, or increases social mobility, still does not end poverty; it is only a local improvement to some of the conditions of poverty for the residents allowed to remain.

When we first moved to the neighbourhood from a much smaller, more intimate, city, we lived in a kind of denial and passed from our apartment to our distant destinations with minimal attention paid to the space through which we travelled. Eventually, we realized we had lived for a couple of years in a place we hardly knew. And so we decided to get acquainted with our area of residence. We started walking our neighbourhood for at least an hour every weekday, in widening circles of suburban parks, back alleys, and strip malls. Ethnographically examining the space quickly became part of our perambulatory conversations about our family life, Jade's work in a local legal clinic addressing tenancy law crises, Terry's Ph.D. research at York University about the impact of legal consciousness on the creation of literature, the social media drama of our friends back in the Niagara Region that we still obstinately considered home, and other sundry subjects.

On weekends, we walked other neighbourhoods of Toronto. We noted how treed and quiet the most monied neighbourhoods were. Our neighbourhood was a place characterized by "the steady drone of airplanes and traffic" 
("This Human Geography We Inhabit"), where "you [could] look down on seagulls gliding/ within reach of the balcony" ("Balcony Birding") but not hear them, and where the only auditory evidence of one's neighbours was the sounds of their power tools and smoke alarms (see "The Upper World"). By contrast, the strictly upper-class neighbourhoods were so insulated from heavy transit that, from the sidewalk, one could hear not only birds, but conversation. Rather than the smog of vehicle exhaust, one could smell grass, and flowers blooming lushly in the boulevards. The homes there were not over-priced apartments made of "Glass held on by glue" ("Climate Change Denial"); they were older, and hardier, and offered a wood-and-brick privacy not afforded by the relentless transparency of the Panopticondos.

But we did not do anything with our observations until, in 2016, an experimental literary reading series called Draft invited us to perform. The premise of the reading series is to publicly share works in progress, which builds a community of established and new writers by emphasizing a shared sense of creative process. We gamely decided to write some first drafts specifically for the reading. Despite the reading being scheduled a year in advance, we still found ourselves at two weeks to the deadline with no drafts in hand. We sat on our balcony, looking out over all the southern, more beloved parts of Toronto, and tossed around arbitrary, meaningless suggestions for topics. And then we decided it was time to try to love our own troubled neighbourhood a little in the most devoted way we knew how: by writing poetry about it.

So we turned our critical imagination toward writing call-and-response poems about the economy and the social and political geography of it. We individually wrote seven poems each, then traded them and wrote reply poems. Our original texts were a conversation with our neighbourhood, and our response texts were a conversation with each other. The poems are presented in their paired sets and the poets' initials are marked at the bottom of the page of their respective texts. The eight poems that appear here were selected for their relevance to issues of social justice.

It is perhaps obvious to say that it is important to write about Toronto, as it is a city rapidly changing and those changes can have profoundly beneficial or profoundly damaging consequences for the approximately 2.9 million people who call it home. And accordingly, Toronto has been written about extensively. But the more geographically and socially marginal the Toronto neighbourhood, the less it seems to be written about, the less it is perhaps considered at all, despite the fact that its marginalization makes it all the more crucial for there to be sustained social engagement and good city planning to ensure the neighbourhood's growth and its residents' well-being. Better planning, one hopes, would mean that a neighbourhood does not end up with long stretches where "there [are] no graveyard[s]/ but there are five psychics who speak with the dead" ("Old Money").

So it is that we have become convinced of the usefulness of writing poetry about the Downsview-Bathurst Manor-York University Heights intersection. 
We see particular use for poetry which is attuned to the lacunae in the neighbourhood's development and poetry which seeks to engender a shared experience of this place, especially as it feels so often like community here amounts to little more than "watching football [together] in a wordless dive bar" ("The Secret Park"). We do not claim to be the first or the best at achieving either of those objectives, but there is such a dearth of published literary work about these neighbourhoods that we feel any contribution can be meaningful.

These poems provide a kind of snapshot of critical civic consciousness that might only last a moment in a very particular place. Yet the forces that have shaped and are shaping the neighbourhoods of Toronto have long-lasting and far-reaching consequences, as the gravitational pull of a huge population guides provincial, and even national, legislation and policy and warps the flow of people and money around Lake Ontario. 


\section{The Northern Edge of Everything}

We live at the lonely edge of everything, at the centre of nothing.

To the southwest is Downsview, with its long flat stretches of green that belie its former life as a vast farm. Now, it is a geographical identity crisis, trying to hold its park next to its airport, on the ground that used to be a Canadian Forces Base.

The former waiting ground for wars is now the training ground for circuses. A cynical person might ask what the difference is.

To the east is Bathurst Manor, the name implying an aristocracy that doesn't exist in either the public housing apartments or the apartments that look like public housing. The businesses are mostly restaurants or closed.

The restaurants are a pastiche of ethnicities, from the kosher dairy to the jerk joint to the good Mexican restaurant named Guacamole that only lasted a few months and made me wonder if, somewhere far south of here, there is a burger bar called Ketchup.

We live at the place where the subway ends.

On our northwest side, York University Heights is home to the second largest school in the country, a school that has, nevertheless, been waiting decades for the subway line to reach it.

The University of Toronto has train tracks bordering it on three sides, and we might ask if we're not old enough, or not good enough, to have the same, but we're used to the way that Toronto money runs like a river to the lake. 


\section{Balcony Birding}

Seven storeys is the altitude where you can look down on seagulls gliding within reach of the balcony.

If you've been fishing from a rowboat and looked down,

you know what I mean.

See, for your first time, the seagulls' shoulders flex over urban currents.

Now you can be part of the inland scavenger ecosystem spotting the pavement with binoculars, hearing the regular beat of TTC announcements between the gulls, the crows, the cicadas.

Shuttling subways en route to vanishing points under Yorkdale Mall's malachite consumer monument move thousands of people a day who could see us on the balcony counting them with our pointless notebooks, keeping record of colours, species, time of day. They would notice us but for, of course, their disinterested schedules circling on the ground.

The guidebooks on our shelves make life interesting (Jane Jacobs, Mariana Valverde, Jean-Jacques Audobon), in the undecided frontier between Toronto and North York, where no particular economic class has control of billboards, or the driveways where a Porsche parks next to a K-car on blocks, next to a park where a cute skull-painted Juggalo family strollers past a lawyer briefcasing home.

We think we are the only lake people here, us and the seagulls, Niagara region expats with our canoe parked on the far-south shore of Lake Ontario, while we rent our basement parking garage space to the neighbours across the hall (since they asked and we take transit).

This is the Neutral Zone, pure residential, where the most popular restaurant is a gas station staffed by constantly changing Temporary Foreign Workers who define the neighbourhood the most; because we feel like we are also temporary, foreign, 
only living here in order to go to work from convenient Downsview, no home to come back to, rentiers investing only in circles that draw us farther away from wherever the subways go. 


\section{The Upper World}

Neighbours in a high-rise apartment, when they exist to us at all, are just single, hyperbolic traits, like a stable of cartoonish, allegorical horses.

We hear each other only at our loudest, we see each other only in the halls.

The horse that lives above us loves power tools.

Her drill runs eight hours on Saturday, her hammer eight hours on Sunday, her saw all through the week.

I have never seen wood enter or leave the building. She must be a reclusive carpenter, smuggling in small and secret boxes of smaller and more secret boards to turn her cloister into a forest. Her lonely quarters grow closer to her nightly, walls thickening with layers of screws and nails.

The horses in the corner stall are grandparents.

Only grandparents.

They draw two grandchildren, who never seem to grow older or taller, from their apartment to the elevator and back again.

I have never seen them outside;

I have never seen them on another floor.

They are retired racers, restlessly pacing.

There are horses, somewhere, who burn their dinner every night. As dusk flickers across the day, the alarm cries out like it thought it caught scent of a wolf. But there is only ever the smell of horses, eating grain that tastes of smoke without flame.

In our apartment, we walk laps around the kitchen as the TV blares late into the night. We strike notes on a glockenspiel without ever reaching a melody. The cat pleads long and loud for someone we can't see. An angel, perhaps. 


\section{Climate Change Denial}

Downtown Toronto money is so stupid it hurts.

For the first time, serious tornadoes are touching down south of Vaughn.

Meanwhile, in Kansas, houses are built with special metal bands that loop around the roof beams so that the roofs are shredded when a tornado blows them off. Whole roofs, in one piece, otherwise fly for five, six, seven blocks before they land.

Toronto developers don't give a shit.

The city of North York has so little soil that the basements are flooding so often that the councillors will not be able to install backflow valves before the foundations crack.

Toronto developers don't give a shit.

For the first time, in North America, storms are entering high rise neighbourhoods because their winds are traveling faster than ever possible.

Toronto real estate developers are building the high rises out of glass. Glass held on by glue.

Have you ever dropped a jar of spaghetti sauce into an indoor skydiving wind tunnel and watched it shatter on the fan, and dropped another, and another...

The intercity buses drive into Toronto past the lit-up beacons of the future: insurance companies next to the embassies of our biggest global trade partners. 


\section{The Secret Park}

When my friend from Ottawa came to visit, I led us on a walk along the Don River, not because I was convinced there would be anything much to see, apart from an unused ski lift, but it seemed better than roaming the aisles of the grocery store or watching football in a wordless dive bar.

We followed the edge of the water,

then scampered our way up a tangle of steep and unmarked trails.

We were just breaching a field that looked empty, when we heard carnival music lilting over the hill.

Exchanging suspicious glances, we climbed to the crest and found ourselves unexpectedly surrounded by a crowd of families.

Children played lawless games of soccer, parents cooked hot dogs on portable barbecues.

"What is this?" I asked. "Where are we?"

We passed through the crowd and then we were standing in a silver amphitheatre, gleaming in the sun like a crashed UFO.

Beyond was another long stretch of field. We crossed the grass and came out between nondescript apartment buildings on a street I never have reason to travel. From that side, the secret park stretched clear and wide for half a city block. 


\section{No Secrets}

Downsview is impossible,

because everything is as it seems.

Which should be impossible in a democracy.

There are no secret millionaires -

the millionaires are right there.

Poverty is not hidden -

it is in the decrepit houses right next to the expensive condos.

We know exactly what everyone's income is

because every week fliers arrive with condo and house prices and name the streets, and number the people who live there, and other advertisements for home and car loans

let us do some quick math on the back of the mail.

Maps. Statistics. Brokers depict quantifiable details,

tell us to move, tell us the distance from home to work,

which tells us where everybody is supposed to be working; but in this economy it tells us where they have to be working to qualify for the loans to buy the condo which is decorated with either two hundred dollar toasters from Yorkdale Mall or not decorated at all.

Not one speck of personal flair, not even

a poster or a unique lamp shade

behind the statistically transparent, ironically named, blinds. 


\section{This Human Geography We Inhabit}

After three years of living in this apartment, I still feel like we don't belong to the neighbourhoods it touches.

My work and my friends are elsewhere.

This place is for sleeping

and for buying groceries

and for leaving.

The glut of failing businesses suggests

that other residents do the same.

There was one time, though,

when I felt myself almost a part of

this human geography we inhabit.

It was a mild evening in late summer.

The screen door to the balcony

was open for the cat.

I was in the bedroom,

which glowed pale blue like

a cloud preparing for rain.

Over the steady drone of airplanes and traffic,

the wind came in the door

like a string joining tin cans

and I could hear every proclamation made

in the transit station down the street. 


\section{Old Money}

On the bus route between

Downsview and Sheppard-Yonge stations

there is no graveyard

but there are five psychics

who speak with the dead.

English family names appear on street signs

honouring money.

The Grand Orange Lodge has a Benefit Fund headquarters on Sheppard Avenue.

The gentrified real estate is too valuable to portion some of it to the dead.

Nobody wants to spend eternity next to the Orange Order.

The ghosts won't even haunt this place and nobody gathers to share their own grief

which is probably why

some things that should be buried still stand. 